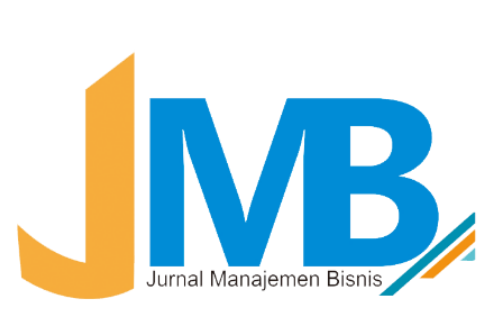

\title{
RECRUITMENT AND SELECTION PRACTICE ON INDONESIA STATE- OWNED ENTERPRISE: A LITERATURE REVIEW
}

\author{
Jafar Basalamah $^{1}$, Muh. Herdiansyah Syahnur ${ }^{2}$, \\ Abdurrahman Basalamah ${ }^{3}$ \\ ${ }^{1}$ Universitas Muslim Indonesia, Makassar, Indonesia \\ ${ }^{2}$ Universitas Muslim Indonesia, Makassar, Indonesia \\ ${ }^{3}$ Universitas Tomakaka, Mamuju, Indonesia \\ Corresponding Author's Email: jafarbasalamah@umi.ac.id
}

Received:10-09-2020 | Revision: 17-10-2020 | Accepted:28-10-2020

To cite this document:

Basalamah, Fajar, Syahnur, Muh. Herdiansyah, Basalamah, Abdurrahman, (2020) "Recruitment and Selection Practice on Indonesia State-owned Enterprise: A Literature Review", Manajemen Bisnis, Vol. 10 No.2, pp.09-16, http://ejournal.umm.ac.id/index.php/jmb/article/view/13093

\begin{abstract}
In modern days recruitment and selection practices has become a challenge within the developing countries. Various companies struggling with personnel challenges due to increasing competent applicants. The labor market focuses on factors affecting recruitment and selection practices on organizational performance and it becomes a challenge for corporate owners. Because of the fact, attracting qualified, skilled and experienced candidates is important and urgent. In this note, relative HR strategy practices bring changes to organizational growth and impact organizational and corporate performance. The purpose of research was to explore factors affecting the recruitment and practice of selection on the company's performance. However, this research provides useful insight into critical literature, evidence and contributes to finding gaps in recruitment and practice selection at the company's performance in particular state-owned enterprises. Therefore, these studies review past literature and secondary data gathered from different sources such as official publications from each authority, website, journal, and books. This critical review emphasized that the recruitment and selection practices were manipulated in the recruitment sector of state-owned enterprise. Therefore, the company faced great difficulties to provide a professional public service.
\end{abstract}

Keywords: Productivity; Recruitment; Selection, State-owned enterprises

\section{INTRODUCTION}

Every company strive to conduct effective recruitment and selection practices to maintain qualified, experienced, and skilled employees for specific positions, but again in competitive job market applicants that have struggling to find a suitable job for their careers (Santos et al., 2020). However, human capital is directly related to sustainable development, overall performance, and the success or failure of any organization. The 
employees in work, quality commitment, and motivation contributes to the performance of company. In fact, employes without skills that high will not do job effectively (Gamage, 2014; Pahos \& Earth, 2019). Similarly hiring wrong candidates or failing to recruit matched candidate results in low performance that impact on workplace failures. Quality practice of retarding service becomes difficult to measure results of company the (Okofu, 2014). Certain effective human resource management (HRM) must find human resources (HR) needs in the company and then recruitment will determine potential candidates for the actual or anticipated organizational void. Since the delivery service and quality of work depend on company to recruit important candidates to conduct proper recruitment and practice of selection. In order to achieve strategic objectives company, recruitment and practice selection ensure to employ the right number of employees to company (Eva, 2018). Although Selase (2018) indicates that a group of skilled employees will benefit from a competitive advantage in maintaining employee commitment to their performance, and employees with the right skills will do a better job for a company and will determine greater expansion for their performance by achieving the objectives company.

A large number of studies have shown that a company expect to have potential capabilities, from applicants such as work experience, qualifications, and interpersonal skills even to when this candidate employees should the master various expertise in utilization technology or system work-based internet. Work experience and qualifications deal in measuring competence regarding the applicant's ability. However, the concept of communication skills seems to be generic term where things this combines many different special skills (Otoo, et al., 2018). They are authorized to provide qualitative services to the public (Omisore \& Okofu, 2014). Several adequate performances are significant for the purpose of company, such as quality and fairness for service delivery (Luballo \& Simon, 2017). In last few years, the level of performance company 's country has declined (Santos et al., 2020). Ali Shameem (2018) has conducted basic organizational research that demonstrates poor performance of service company 's country. Ali Shameem (2018) says $1 / 3$ survey report of respondents had poor perception of civil service performance. Study by Santos et al (2020) also emphasized that there is a huge impact on the market of civil service sector work around the world. It is believed that recruitment and selection could be a factor that provides better service and has a high influence on performance company. Based on the literature given, it is evident that recruitment and selection practices network and political preferences for some of the public sector and private company (Okofu, 2014 ). In the current competitive global community, it is important to choose qualified applicants for a sustainable organizational success. Research by Rahmany (2018) mention that ensured company will give effect in recruitment and selection practices on performance company. Tella \& Ibinaiye (2019) said that skills and employee capabilities not only lead to individual performance, but also will affect performance company overall, efficiency and effectiveness in providing services. Luballo \& Simo (2017) confirms that when employment decisions are made based on corrupt, favoritism, discrimination cause, selection of unqualified employees who do not have the 
right knowledge, skills, and abilities will not add value to company. Sarah et.al., (2018) expressed the negative characteristics of this disclosure leading to undue frustration and eventual recruitment and selection practices extensively influencing performance company. Joy et al., (2015) stated it is crucial to draw the right number of qualified applicants in the recruitment and practice selection. Thus, the selection plays an important role to select the most suitable applicant (Okusanya \& Oseji, 2012). The better the recruitment target and selection criteria improve organizational performance and efficiency (Okusanya \& Oseji, 2012). However, this research highlights factors that influence recruitment and practice of selection on the civil service organization's performance in the context of Indonesia. The purpose of this research is to provide a better strengthening of understanding for further study.

\section{LITERATURE REVIEW}

In HRM, recruitment and selection are the core functions most influential to the organization's performance (Harky, 2018). As a job analysis is the first step in the practice of recruitment and selection then it is important for every organization and also the applicants. If the organization does not require work, then recruitment and selection are not required. According to Santos et al. (2020) the aim of recruitment and practice selection is to choose and put the best people in fulfilling the workplace needs to develop and maintain the quality of service. Therefore, recruitment and selection practices are crucial and play an important role in the functioning of the success, effectiveness, and performance of the organization (Harky, 2018). To improve staff performance when organizations adopt a performance-oriented culture (Musah et al., 2017). In particular, if the organization has fair recruitment and selection practices without distinguishing the merit-base system in the organization ( Pahos \& Galanaki, 2019 ). In HRM, recruitment and selection are the first step, and the employee's performance assessment is the last step to identifying the success or failure of any organization (Oaya, Ogbu, \& Remilekun, 2017). Therefore, it is important, honest, successful, and independent to pass all stages of recruitment and selection (Okusanya \& Oseji, 2012). However, these subdivisions review the recruitment relationships and practice selection on performance and how the theory and model of current practice with empirical evidence (Alhassan, et al., 2014).

Employee performance demonstrates how well staff do their work and the success of each organization. The key factors of employee performance are integrity, reliability, and honesty to perform their job responsibilities (Santos et al., 2020). The available studies focus on the correlation of employee competency skills with their contextual performance (Ofori \& Aryeetey, 2011). It also attempts to address the research gaps for recruitment and selection practices on work skills, knowledge, experience, and strategic policies and other political pressures and contextual performance from government employees (Usmani, 2020). These work skills are diversified into various categories such as basic academic skills, high thinking skills, personal qualities, and various other skill sets (Abas \& priests, 2016). When hiring new staff Most employers consider this skill 
because it plays an important role in both job and organizational success (Oaya et al., 2017 ). Ekwoaba et al., (2015) emphasizes that organizational weakness or strength comes from recruitment and practice selection, for example, strategic policies facilitate to obtain more qualified employees who will lead to organizational performance. Abas \& Priests (2016) noted that organizational development and growth depends on the ability of recruitment and practice of selection. In the case study of Rahmany (2018) new Afghanistan employed prospective public servants are not worthy to understand their job duties. In recruitment and selection of civil servants practice shortlists, applicants are based on bribery relationships, political influences, and nepotism. This gives the organization a negative impact that will ultimately lead to poor administrative performance. Similarly, that current recruitment and practice selection is not as effective as is required in the Ethiopian region. The procedures are violated, and they do not have the proper monitoring and evaluation system.

In the general principle that based merit is not strictly considered to support recruitment and selection that leads to poor performance of the civil service sector (Ferede \& Sidemo, 2018). In the survey report, Ali Shameem (2018) 67.16\% of the community believes, civil service organizations are unaware of the services they provide. $53.19 \%$ of people believe that civil service work is biased and politically influenced in providing services. This report indicates that the civil service organization has failed to achieve the organizational goals that have been designed for. Also, such violations and political interference of politicians, civil service organizations are filled with individuals who are not qualified to provide professional services. In addition to Pahos et al., (2019) the country's recruitment and practice selection should consider eliminating stereotypes about older and younger employees. Because age also has a positive impression on the overall performance of an organization (AL-Jubari, 2014). Considering that HRM professionals and practitioners are very important to know that old age employees are valuable assets. When retaining and attracting staf mature employee staff can influence a positive organization (Hassan \& Jubari, 2010 ). According to Matolo et.al., (2019) Proper recruitment and selection has increased the low turnover staff who affirm analytically checked to have better performance. Gamage (2014) states that it is important to know the objectives, policies, and practices used for selection. Recruitment and selection practices comply with rules, regulations and code of ethics that ensure to maintain fair and equitable treatment for all applicants (Rahmany, 2018).

Merit is known as a single characteristic. The characteristics of the whole community are called meritocracy (McNamee and Miller, 2009). Therefore, meritocracy systems are social systems in which individual proportions are identified based on procedures and skills, and this can be run with the help of merit system. McCrudden (1998) found five different concepts of merit-system. The first concept is known as fairminded, no special treatment. The second concept is a matter of fact, the model requires the potential need to achieve a generally valuable goal for the community. The third concept is merit related to strick job or importance, this requires a close match between the tool and the goal to be achieved. The fourth concept is merit as a special skill and 
procedures of work-related outcomes. It is also anticipated to choose a broad view of the elements of the work (Setyowati, 2016). This system requires a person to be evaluated based on the ability to demonstrate knowledge, skills, and abilities (KSA). When government agencies open jobs, each position lists requirements such as background, education, knowledge, skills, and certain abilities (Moon \& Hwang, 2013 ). The US merit system was reformed in 1880. This system creates two new federal agencies namely Personal Management (OPM) and Merit System Protection Board (MSPB) (Moon \& Hwang, 2013). Similarly, in 2005, China introduced a civil service scope to the establishment of civil Service law (Moon \& Hwang, 2013). Australia has begun its main legal framework for the Public Service Act 147 (1999) and New Zealand does the same for the Crown Entity Act (2004) (Moon \& Hwang, 2013). In 2006, Korea implemented a senior civil service system; traditional hierarchical and seniority systems which were later transformed into performance-based systems and competencies (Moon \& Hwang, 2013). In the same way, the Maldives civil service ACT 5/2007 was established as an independent body that defines the legal status, purpose, and responsibility of public service. Civil Service Regulation (2014), 2014/R-311 was established on 1 December 2014. Since then, Maldives has been following merit-based recruitment and selection systems where it is selected based on academic service, skills and experience based on civil service.

The resource-based view theory was formed in 1959. This theory is mainly focused on analyzing the relationship between HRM practice and delivery service. Based on a theoretical view-based resource it makes sure to maintain a competitive edge by evaluating the workforce, whether the organization has the right amount of the right skilled staff in the right place (Barney, 2001). The main part of this theory holds organizational weaknesses and strengths that stem from the employees ' ability to work relationships and their quality of work. Boxall (1998) determines that their organization that recruits better applicants has the capacity to generate human capital gains in the organization. Luballo and Simon (2017) mention that the previous day-based remorse view theory is considered to learn the relationship between recruitment, exercise selection and performance management practices to provide quality services in the country-government. But the current resource-based View theory is a suitable framework for emphasizing recruitment and selection exercises and performance management as a primary gadget for achieving organizational objectives.

\section{RESEARCH METHOD}

This study examines past literature and secondary data gathered from a variety of sources such as, official publications from individual authorities, websites, journals, and books. This critical literature is focused on identifying recruitment and selection practices on the performance of state-owned enterprises in terms of expanding their scope in this context. The articles are selected based on the topic of the most relevant region and the data sources collected to reinforce the evidence of this study. Therefore, the literature of this study was reviewed to determine a good design for qualitative 
surveys as a field of knowledge (Beatty, 2005). However, this theoretical framework will provide clear justification for factors affecting recruitment and practice of selection and their nature in the performance of the company. The main objective of this study is to understand the nature of the study, the factors influencing recruitment and selection practices on the performance of state-owned enterprises in the context of recruitment and selection in Indonesia. To strengthen quantitative research studies, it will be done blatantly to find the problem, while further analysis will answer research objectives and fill the research gap.

\section{RESULT AND DISCUSSION}

Most of the literature shows that HR manager critically affects recruitment and selection practices. The overqualified where the staff dissatisfied with their work because their qualifications and also ineligible and less skilled from staff where they cannot do job well, because of lack of competency knowledge, skills and abilities. (Van Dijk, Shantz, \& Alfes, 2019). According to Armanu et.al. (2020) generally HR planning that improper will creating problems in recruitment and selection policies. The focus of HR planning is to employ employees that skilled and experienced. Job skills are requirements for entry at each level at work (Abas \& Imam 2016). HR planning interprets organizational strategy into specific HRM policies natural practice selection. In addition, recruitment and selection will fails when a company have analytics data insufficient work, no important information and improper selection strategy. However, the evidence available confirms the positive bonds of recruitment and selection practices on performance (Santos et al., 2020). The recruitment and selection strategies combine and evaluate through four individual indicators.

This indicator supplies qualified manpower on time, the right job analysis and job descriptions, have effective selection practices, and contributions from direct employers. In addition, the Tribe Ekwoaba et al., (2015) said that the recruitment procedures and the knowledgeable selection will have a positive impact on the performance company. Usmani (2020) stated that HR practitioners need to to understand the various factors required for recruitment and selection practices that will not violate potential candidate rights. Research suggests that it is important to select or employ candidates based on knowledge, qualifications, relevant skills, and the level of trust of applicants. The research confirms that recruitment and selection practices have a positive correlation between performance company (Gamage, 2014). Darkoh (2014) stressed that hiring a lower employee her skills then company will less effective and more likely to experience the impact bad in providing services. When company hiring employees that not have competence and skills that adequate, their turnover rate will low and will result in poor performance. On this critical literature, it is important to have HRM with the correct structure that have integrity, motivated, trained, and enthusiastic in improve the company (Agus Salim W, 2018). Therefore, the correct recruitment and selection with good system then potential skilled employees will improve the performance of company (Eva, 2018). Each fair recruitment and practice selection will create more opportunities to gain the 
right candidate employees to the right job and right. To ensure the effectiveness of company, precise recruitment and selection strategies will help to allocate the right number of employees for a suitable position. If recruitment and selection practices manipulated by someone in favour, recruitment and employees may not have independence in carrying out its duties. Therefore, the results of the company performance may not be expected from employees who have chosen by manipulation, political influence, or corruption that affects the practice of selection. Anyango et al., (2018) stated that not only does the organizational selection practice decide who is employed, but also the appropriate selection criteria increase the likelihood of choosing the right candidate. If company choose the right candidate with proper employment criteria, then employees will work well and efficiency company will increase (Anyango et al., 2018). In this research, if company have skilled, qualified, and experienced rights then company will perform better in providing that service. It be associated to minimize turnover rates company, low achievement, and unsatisfied customers and it mutually beneficial to both employee relations and high commitment (Andy et al., 2017).

\section{CONCLUSION}

Most of the research has proved the connection between recruitment and the practice of selection influencing, and the success impact of the organization. Therefore, based on this critical literature review study factors that influence the recruitment and practice of selection at predictable performance to develop conceptual framework studies. This study analyzes that recruitment and selection practices play an important role in the company 's efficiency and provide quality services. Therefore, it is important for HR practitioners to understand the objectives, policies, and practices used for recruitment and selection practices. As shown if the organization adopts better recruitment and selection practices, it will positively impact the company's performance and service efficiency. This study contributed a significant contribution to developing the literature on factors affecting the recruitment and practice of the performance selection of state-owned enterprises. Based on the results of this study, it is important to undertake quantitative research to find problems and to analyze recruitment and selection of employee research gaps in the context of state-owned enterprises.

\section{REFERENCES}

Akuamoah, W., Kofi, A., Yao, B. D., \& Kafui, L.-A. (2017). The Impact of Effective Recruitment and Selection Practice on organisational Performance (A Case Study at University of Ghana). Global Journal of Management and Business Research.

Al-Jubari, I. (2014). Exploring employee work engagement in academia: A qualitative study. Journal of Education Research and behaviorial Science, 3 (6), 169-178.

Al-Jubari, I., Mosbah, A., \& Talib, Z. (2019). Do intrinsic and extrinsic Motivation Relate to Entrepreneurial Intention Differently? A Self-Determination Theory Perspective. Academy of Entrepreneurship Journal.

Alhassan, M. A., Zulkipli, G., \& Nizam Isha, A. S. (2014). Role of Organizational Culture, Organizational Communication and Temperament in the Choice of Conflict Management 
Styles among Plant Turnaround Maintenance Employees in PETRONAS Petro-Chemical Companies in Malaysia: A Conceptual Framework. Global Business \& Management Research, 6 (4).

Ali Shameem, A. S., Aminath mazini. (2018). Customer Perception reserch Maldives Civil Service Conference 2018 Paper, 3.

Anyango, E., Walter, O. B., \& Muya, J. (2018). Effects of Recruitment and Selection Criteria on Organizational Performance at Kisii University, Kenya.

Beatty, P. (2005). Robert M. Groves, Floyd J. Fowler, Mick P. Couper, James M. Lepkowski, Eleanor Singer, and Roger Tourangeau. Survey Methodology. Hoboken, NJ: Wiley interscience. 2004.448 pp.: Oxford University Press.

Civil Service Commission Male ', M. (2014). Maldives Civil Service Regulation No.: 2014/R311.

Ekwoaba, J. O., Ikeije, u. U., \& Ufoma, N. (2015). The Impact of Recruitment and Selection Criteria on Organizational Performance.

Eva, T. P. (2018). Recruitment and Selection Strategies and Practices in the Private Sector Commercial Banks of Bangladesh: Evidence from Human Resource Practitioners. European Business \& Management, 4 (1), 28-38.

Ferede, m. M. T., \& Sidemo, m. E. K. (2018). A Study on assessment of recruitment and selection practices and its challenges in civil service Bureau of Benishengul gumz RegionEthiopia. Journal Homepage: http://www. Ijmra. US 8 (1).

Gamage, A. S. (2014). Recruitment and selection practices in manufacturing SMEs in Japan: An analysis of the link with business performance. Ruhuna Journal of Management and Finance, 1 (1), 37-52.

Harky, Y. F. M. (2018). The Significance of Recruitment and Selection on Organizational Performance: The Case of Private Owned Organizations in Erbil, North of Iraq. Istanbul Aydin University Institute of Social Sciences.

Hassan, A., \& Jubari, I. H. A. A. (2010). Organisational Justice and employee work engagement: LMX as mediator. Journal for International Business and Entrepreneurship 